\title{
MENEMUKAN KESALAHAN GRAMATIKA DALAM ESAI MAHASISWA BAHASA INGGRIS DAN SOLUSI MENGHINDARINYA
}

\author{
Puspita Sari danYasinta Dwi Putri \\ Univeritas Widyatama Bandung, Indonesia
}

\begin{abstract}
ABSTRAK
Menulis esai dalam Bahasa Inggris yang baik merupakan salah satu kemampuan penting yang harus dimiliki oleh mahasiswa di Prodi Bahasa Inggris. Maka dari itu, mata kuliah menulis (writing) telah diberikan kepada mahasiswa sejak awal semester.Namun, seringkali ditemukan kesalahankesalahan gramatika yang muncul pada esai karya mahasiswa, misalnya kesalahan-kesalahan berbentuk omission, addition, misformation, dan misordering seperti dalam teori Dulay et. al (1981). Penelitian ini bertujuan untuk menemukan kesalahan-kesalahan umum gramatika yang dilakukan mahasiswa Semester III Program Studi Bahasa Inggris dalam menulis esai Bahasa Inggris, serta memberikan solusi untuk menghindarinya sehingga menghasilkan esai yang berterima. Tahapan yang dilakukan adalah mengumpulkan data esai mahasiswa, menemukan bentuk kesalahannya, menganalisis, dan mencarikan solusi sehingga kesalahan-kesalahan tersebut dapat dihindari dan tidak terulang. Dari penelitian ini dapat disimpulkan bahwa kategori misformation yang merupakan kesalahan bentuk paling mendominasi, diikuti oleh omission dan addition. Adapun kesalahan yang memiliki prosentase terendah adalah misordering.
\end{abstract}

Kata kunci: esai, gramatika, omission, addition, misformation, dan misordering.

\section{Pendahuluan}

Menulis esai merupakan salah satu bentuk kegiatan perkuliahan yang sering dilakukan oleh mahasiswa bahkan menjadi hal terpenting yang harus dapat dilakukan oleh mahasiswa. Seperti dikemukakan oleh Gebhard dan Rodriguess (1989:1) "Writing is one of the most importhan things you do in collage".Meskipun kegiatan tersebut sering dilakukan, tidak jarang mahasiswa melakukan kesalahan-kesalahan yang berkaitan dengan format penulisan maupun tata bahasa. Prinsip menulis dalam bahasa Indonesia dan bahasa Inggris tidak jauh berbeda, misalnya dalam satu kalimat baik Bahasa Indonesia maupun Bahasa Inggris harus memiliki unsur subjek dan predikat. Namun, ada hal dalam struktur gramatika yang digunakan pada Bahasa Inggris berbeda dengan struktur gramatika yang digunakan pada Bahasa Indoensia. Kalimat Bahasa Indonesia “ Ayah saya dokter” dalam Bahasa Inggris seharusnya "My father is a doctor" namun kesalahan yang kadangkala dilakukan mahasiswa ditulis dengan "My father doctor (hilangnya to be 'is') atau My father is doctor (hilangnya 
unsur artikel ' $\boldsymbol{a}^{\prime}$ )'. Hal ini menunjukkan bahwa pengaruh bahasa ibu (Bahasa Indonesia) kadangkali berpengaruh terhadap esai yang ditulis mahasiswa dalam bahasa Inggris.

Kesalahan-kesalahan gramatika tidak hanya dilakukan oleh mahasiswa di luar Program Studi Bahasa Inggris, tetapi juga dilakukan oleh mahasiswa Program Studi Bahasa Inggris yang memang mempelajari tata bahasa/struktur Bahasa Inggris secara khusus pada mata kuliah tertentu, yaitu mata kuliah Grammar. Terdapat mahasiswa yang sering menggunakan format bahasa ibu (Bahasa Indonesia) yang diterjemahkan kedalam Bahasa Inggris, sementara struktur gramatika bahasa ibu (Bahasa Indonesia) berbeda dalam Bahasa Inggris. Dulay et. al. (1981) mengatakan bahwa kesalahan yang terjadi dalam analisa kalimat sering kali berbentuk kesalahan omission, addition, misinformation, dan misordering. Seperti pada kalimat "I can be journalist better than him. "Terdapat kesalahan omission atau penghilangan article " $a$ " sebelum nomina "journalist" yang berfungsi sebagai penjelas nomina (journalist). Maka seharusnya kalimat yang tepat adalah "I can be a journalist better than him. "Pada dasarnya dalam proses pembelajaran Bahasa Inggris yang merupakan bahasa kedua, seorang pembelajar tidak lepas dari kesalahan-kesalahan gramatika seperti itu karena pembelajar bahasa kedua bukan merupakan penutur asli dari bahasa tersebut. Oleh karena itu, perlu ada proses pembelajaran untuk memperbaiki kesalahan tersebut agar dapat meningkatkan kemampuan berbahasanya, khususnya menulis esai sehingga dapat berterima baik secara gramatika dan maknanya.

\section{Permasalahan}

Kesalahan merupakan hal yang sering muncul dalam esai yang dibuat oleh mahasiswa. Berdasarkan hal tersebut, penulis mengidentifikasi masalah sebagai berikut:

1. Kesalahan umum gramatika apa saja yang terdapat dalam esai mahasiswa?

2. Bentuk kesalahan apa yang paling mendominasi dilakukan oleh mahasiswa?

3. Bagaimana cara menghindari kesalahan tersebut?

\section{Tujuan Penelitian}

Berdasarkan pada identifikasi masalah di atas, penelitian ini bertujuan untuk:

1. Mengetahui kesalahan umum gramatika apa saja yang terdapat dalam esai mahasiswa.

2. Mengetahui bentuk kesalahan apa yang mendominasi dilakukan oleh mahasiswa.

3. Menemukan solusi bagaimana menghindarinya.

\section{Objek Dan Metode Penelitian}

Objek penelitian ini adalah dua puluh esai mahasiswa dengan tema "Who Am I"yang diperoleh dari dua puluh orang mahasiswa Prodi Bahasa Inggris Universitas Widyatama Bandung pada semester III yang menempuh mata kuliah Essay WritingI. Sedangkan metode penelitian yang digunakan adalah metode deskripstif kualitatif. Metode ini dibagi kedalam tiga tahapan (Sudaryanto, 1993:5-7):

(1) Tahap Pengumpulan Data, yaitu mengumpulkan esai mahasiswa Prodi Bahasa Inggris. Esai yang diperoleh merupakan esai deskriptif untuk mengetahui gambaran dan bentuk kesalahan gramatika apa saja yang ditulis oleh mahasiswa. 
(2) Tahap Analisis Data, yaitu megemukakan medote kualitatif yang menghasilkan data deskriptif berupa kata-kata tertulis dari mahasiswa yang diperoleh dari tugas harian mahasiswa semester III yang menghasilkan data deskriptif berupa penjelasan kesalahan-kesalahan gramatika yang dilakukan oleh mahasiswa dalam membuat esai Bahasa Inggris.

(3) Hasil Penelitian disajikan dalam bentuk deskriptif dengan menyertakan tabel kesalahan yang telah diklasifikasikan menurut jenis kesalahannya. Hasil penelitian juga disajikan dalam bentuk persentase kesalahan pada tiap-tiap klasifikasi kesala han gramatika.

\title{
Tinjauan Teori
}

\begin{abstract}
Kalimat
"Orthographically and rhetorically, a sentence is that unit which starts with a capital letter and ends with full stop, a question mark or an exlamation mark”'Downing(2006:272). Sebuah kalimat adalah sekelompok kata yang memiliki makna lengkap, dan dapat berdiri sendiri, dan diikuti oleh tanda titik, tanda tanya, atau tanda seru. Kalimat juga merupakan ujaran yang memiliki struktur minimal Subjek (S) dan Predikat (P) dan intonasinya menunjukkan bagian ujaran itu sudah lengkap dengan makna.
\end{abstract}

Contoh: $\quad$ Iwentto the movielast night.

S V Adv of place Adv of time

\section{Kelas Kata}

Kelas kata atau jenis kata (part of speech) merupakan suatu sistem yang diperlukan untukmembentuk sebuah kalimat tanpa melihat apa tugas atau fungsinya masing-masing. Seperti menurut Delahunty dan Garvey (2010:77)menyatakan bahwa kelas kata dibagi menjadi dua kelompok yaitu lexical (major) yang terdiri dari nomina (noun), verba (verb), adjektiva(adjective), dan adverbia (adverb), dan grammatical (minor) yang terdiri dari preposisi (preposition), pronomina(pronoun), kata sandang(article), dan konjungsi (conjunctions). Dengan kata lain, kelas terdiri dari delapan unsur dan setiap unsur memiliki peran tersendiri dalam membangun suatu kalimat, klausa, ataupun frasa.

\section{Gramatika}

Definisi yang dikemukakan oleh Lewis(1993) yang menyatakan bahwa gramatika sebagai rangkaian bentuk kalimat yang di dalamnya terdapat kata-kata yang sesuai yang bisa ditempatkan. Adapun pendapat Paulston(1976) menyatakan bahwa gramatika sebagai bentuk dan penyusunan kata yang berterima dalam frasa dan kalimat.Dari kedua penjelasan di atas, dapat dikatakan bahwa gramatika merupakan susunan kata-kata yang mengikuti aturan tertentu untuk membentuk suatu satuan yang lebih besar, seperti klausa atau kalimat.

\section{Analisis Kesalahan}

Pada proses pembelajaran, terdapat beberapa kesalahan yang sering dilakukan oleh pembelajar bahasa, yaitu kekeliruan (mistake) dan kesalahan (error). Pendapat James (1998) 
membahas perbedaan antara istilah error yang berarti kesalahan, dan mistake yang berarti kekeliruan. Error atau kesalahan yang dimaksud disebabkan oleh faktor pemahaman, kemampuan atau kompetensi. Apabila pembelajar melakukan kesalahan karena belum memahami sistem linguistik bahasa yang sedang dipelajari, maka hal tersebut dikatakan sebagai kesalahan atau error, dan selanjutnya dapat diperbaiki dengan cara mempelajari kembali bahasa yang sedang dipelajari.Sedangkan kekeliruan atau mistake tidak disebabkan oleh ketidakpahaman pembelajar bahasa terhadap bahasa yang digunakan melainkan memahami bahasa yang digunakan namun lupa atau keliru saat menggunakannya, dan untuk memperbaiki kekeliruan yang dilakukan, pembelajar bahasa dapat langsung memperbaiki kekeliruan yang dilakukan tanpa harus mempelajari kembali bahasa tersebut.

Ellis, Rod dan Barkhuizen (2005) menyatakan bahwa analisis kesalahan merupakan proses penentuan peristiwa, kejadian, penyebab, dan akibat dari kegagalan bahasa. Dapat dikatakan pula bahwa analisis kesalahan dilakukan sebagai upaya untuk mengetahui kesalahan-kesalahan yang ada dan dapat menjadi bahan evaluasi untuk perbaikan kedepannya.

Terdapat beberapa jenis analisis kesalahan, seperti yang juga diungkapkan Ellis, Rod and Barkhuizen (2005) yang menyatakan bahwa ada dua jenis taksonomi yang digunakan, yaitu (1) taksonomi linguistik; kesalahan berbahasa berdasarkan pada butir linguistik (fonologi, morfologi, sintaksis, dan leksikon), dan (2) taksonomi struktur permukaan; berhubungan dengan struktur kalimat, frasa verba, pelengkapan verba, frasa nomina, frasa preposisi, keterangan, kata penghubung, dan kata penghubung anak kalimat, dan sambungan kalimat. Pada penelitian ini, penulis menggunakan salah satu teori James (1998) mengenai analisis kesalahan, yaitu taksonomi struktur permukaan karena penelitian yang dilakukan berdasarkan kesalahan gramatika.

Sementara Dulay, Burt, dan Krashen's (1981:150) mengemukakan bahwa taksonomi struktur permukaan terbagi kedalam empat kategori umum dengan sub-kategorinya, yaitu:

a. Omission (penghilangan)dicirikan oleh hilangnya sesuatu yang harusnya dimunculkan dalam bentuk ujaran yang benar.

Contoh :

\begin{tabular}{|l|l|}
\hline Kesalahan karena omission & Kalimat yang benar \\
\hline You are good student. & You are a good student. \\
\hline
\end{tabular}

b. Addition, merupakan kebalikan dari omission, yaitu penambahan. Addition dicirikan dengan hadirnya sesuatu yang seharusnya tidak ada dalam ujaran yang tersusun dengan benar. Terdapat 3 jenis kesalahan dalam Addition, yaitu (a) Double Marking(penanda ganda), (b)Regularization, dan (c) Simple addition.

Contoh:

\begin{tabular}{|l|l|}
\hline Kesalahan karena Addition & Kalimat yang benar \\
\hline $\begin{array}{l}\text { They didn't went here.(Penanda } \\
\text { tenses ganda) }\end{array}$ & They didn't go here. \\
\hline $\begin{array}{l}\text { I saw the mans over } \\
\text { there.(regularization :bentuk } \\
\text { jamak) }\end{array}$ & I saw the men over there. \\
\hline
\end{tabular}


c. Misformation, dicirikan oleh penggunaan bentuk bentuk yang tidak dapat diterima morfem atau kalimat. Pada kesalahan pembentukan ini, pembelajar menyertakan sesuatu walaupun yang disertakannya adalah salah. Ada tiga bentuk misformation ini, yaitu (1) RegularizationError, misal: runned seharusnya run, sheeps seharusnya sheep, (2)Archiforms, misalnya that cats seharusnya those cats, dan (3) Alternating Form, misalnyaHe seen you Yesterdaydan He would have saw them.

d. Misordering, yaitu penempatan morfem atau kumpulan morfem yang tidak tepat pada ujaran.

Contoh:

\begin{tabular}{|l|l|}
\hline Kesalahan karena Misordering & Kalimat yang benar \\
\hline I don't know who is he. & I don't know who he is. \\
\hline What you are thinking about? & What are you thinking about? \\
\hline
\end{tabular}

\section{Pembahasan}

Penelitian ini diawali dengan mengumpulkan hasil esai mahasiswa pada Semester III. Jumlah esai berasal dari 20 esai karya mahasiswa. Setelah data terkumpul dilakukan penentuan kesalahan-kesalahan gramatika apa saja yang dilakukan mahasiswa pada esai yang ditulisnya dan menganalisis kesalahannya.

Kesalahan umum gramatika yang dilakukan mahasiswa dalam menulis esai meliputi kesalahan:

\section{a. Omission}

Beberapa mahasiswa melakukan kesalahan omission atau penghilangan seperti penghilangan article " $a$ " pada kalimat "I can be journalist better than him." Kalimat tersebut merupakan penggalan kalimat yang diperoleh dari esai responden A. Dalam kalimat formal, article digunakan sebagai pelengkap nomina, termasuk juga profesi seperti diungkapkan Thomson and Martinet (1986). Maka, dalam kasus ini article " $a$ " seharusnya mengawali nomina journalist yang merupakan

profesi seseorang. Sehingga kalimat yang tepat seharusnya adalah "I can be a journalist better than him."

Bentuk kesalahan omission lain yang dilakukan mahasiswa seperti pada tabel 1 di bawah ini.

Tabel 1. Contoh Kesalahan Omission

\begin{tabular}{|l|l|l|l|}
\hline No & $\begin{array}{l}\text { Kalimat pada esai } \\
\text { mahasiswa }\end{array}$ & Kalimat yang seharusnya & \multicolumn{1}{|c|}{ Jenis } \\
\hline 1 & $\begin{array}{l}\text { I am not the oldest among all } \\
\text { of my friends, but my friends } \\
\text { call me "Bunda" because } \\
\text { they thought that I look } \\
\text { mature than others. }\end{array}$ & $\begin{array}{l}\text { I am not the oldest among all of } \\
\text { my friends, but my friends call } \\
\text { menda" because they } \\
\text { thought that I look mature than } \\
\text { the others. }\end{array}$ & $\begin{array}{l}\text { Omission pada article } \\
\text { the' }\end{array}$ \\
\hline 2 & $\begin{array}{l}\text { Graduated from vocational } \\
\text { high school 10 }\end{array}$ & $\begin{array}{l}\text { I graduated from vocational } \\
\text { high school 10 }\end{array}$ & $\begin{array}{l}\text { Omission unsur Subject } \\
\text { I'(pronoun) }\end{array}$ \\
\hline 3 & $\begin{array}{l}\text { I actually a sceptic person. } \\
\text { I am actually a sceptic person. }\end{array}$ & $\begin{array}{l}\text { Omission unsur to be } \\
\text { yaitu 'am' }\end{array}$ \\
\hline
\end{tabular}




\section{b. Addition}

Selain omission, beberapa mahasiswa juga melakukan kesalahan addition atau penambahan seperti kesalahan penambahan to be pada salah satu kalimat seperti "One of my "imaginary" friend, is become my best friend." Kalimat tersebut diperoleh dari esai responden E, dan termasuk kedalam kategori double marking. Kesalahan penambahan to be yang terdapat pada kalimat di atas adalah penambahan to be "is" yang diletakkan sebelum verba become. Jika dilihat dari polanya, kalimat tersebut termasuk kedalam kalimat sederhana.Kalimat sederhana hanya memiliki satu subjek dan satu verba utama. Sedangkan pada kalimat di atas terdapat dua verba, yaitu "is" dan "become". Dengan kata lain, penulis seharusnya tidak perlu menggunakan to be "is" untuk menerangkan become.

Bentuk kesalahan addition lain yang dilakukan mahasiswa seperti pada tabel 2 di bawah ini.

Tabel 2. Contoh Kesalahan Addition

\begin{tabular}{|c|c|c|c|}
\hline No & $\begin{array}{l}\text { Kalimat pada esai } \\
\text { mahasiswa }\end{array}$ & Kalimat yang seharusnya & Jenis \\
\hline 1 & $\begin{array}{l}\text { I am a fun-loving person but I } \\
\text { can be serious, it is depend on } \\
\text { the condition. }\end{array}$ & $\begin{array}{l}\text { I am a fun-loving person but I } \\
\text { can be serious, it depends on } \\
\text { the condition }\end{array}$ & $\begin{array}{l}\text { Addition unsur tobe 'is' } \\
\text { setelah base verb }\end{array}$ \\
\hline 2 & $\begin{array}{l}\text { I am sure that others will like } \\
\underline{\text { to } u s .}\end{array}$ & $\begin{array}{l}\text { I am sure that others will like } \\
\text { us. }\end{array}$ & $\begin{array}{l}\text { Addition } \\
\text { preposition 'to' } \begin{array}{r}\text { unsur } \\
\text { setelah } \\
\text { verba 'like' }\end{array}\end{array}$ \\
\hline 3 & $\begin{array}{l}\text { I hate being a passive } \\
\text { smoker.both its smoke and its } \\
\text { scare drive me stress. }\end{array}$ & $\begin{array}{l}\text { I hate being a passive } \\
\text { smoker.both its smoke and } \\
\text { scare drive me stress. }\end{array}$ & Addition: pronoun 'its' \\
\hline
\end{tabular}

\section{c. Misformation}

Misformation merupakan kesalahan bentuk yang paling banyak dilakukan. Berikut ini adalah kesalahan bentuk penggunaan preposisi "on" pada kalimat "I live in Bandung on Sulaksana Street." Kalimat tersebut diperoleh dari esai responden J. Preposisi "on" digunakan untuk menyatakan hari, bulan, dan letak suatu benda, sedangkan pada kalimat di atas preposisi "on" digunakan untuk menyatakan alamat yang seharusnya menggunakan preposisi " $a t$ " karena letak lokasi yang disebutkan lebih spesifik.

Bentuk kesalahan misformation lain yang dilakukan mahasiswa seperti pada tabel 3 di bawah ini.

Tabel 3. Contoh Kesalahan Misformation

\begin{tabular}{|c|c|c|c|}
\hline No & $\begin{array}{c}\text { Kalimat } \\
\text { pada esai mahasiswa }\end{array}$ & $\begin{array}{c}\text { Kalimat yang } \\
\text { seharusnya }\end{array}$ & Jenis \\
\hline 1 & I give it last week. & I gave it last week. & $\begin{array}{l}\text { Misformation: } \\
\text { pemilihan verb"give- } \\
\text { gave"sesuaikalawaktuat } \\
\text { au tense }\end{array}$ \\
\hline 2 & $\begin{array}{l}\text { A lot of people tells me } \\
\text { that I am a kind hearted } \\
\text { person. }\end{array}$ & $\begin{array}{l}\text { A lot of people tell me that } \\
I \text { am a kind hearted } \\
\text { person. }\end{array}$ & $\begin{array}{l}\text { Misformation: verb } \\
\text { 'tells-tell'(S-V } \\
\text { Agreement) }\end{array}$ \\
\hline 3 & $\begin{array}{l}\text { The things that I bought } \\
\text { is useless. }\end{array}$ & $\begin{array}{l}\text { The things that I bought } \\
\text { are useless. }\end{array}$ & $\begin{array}{l}\text { Misformation: singular- } \\
\text { plural form (is-are) }\end{array}$ \\
\hline
\end{tabular}




\section{d. Misordering}

Terakhir adalah misordering atau kesalahan susun seperti yang terdapat pada kalimat "I must hard working to reach that." Kalimat tersebut diperoleh dari esai responden F. Kesalahan yang terdapat pada kalimat tersebut adalah pada frasa "hard working" yang seharusnya adalah "work hard". Kesalahan terjadi karena setelah verba bantu "must" harus diikuti oleh verba utama "work" lalu verba utama diperjelas oleh adverb "hard" untuk menjelaskan bagaimana subjek melakukan aktifitasnya (work), sehingga jika disusun akan menjadi "I must work hard".

Bentuk kesalahan misordering lain yang dilakukan mahasiswa seperti pada tabel 4 di bawah ini.

Tabel 4. Contoh Kesalahan Misordering

\begin{tabular}{|l|l|l|l|}
\hline No & $\begin{array}{l}\text { Kalimat } \\
\text { pada esai mahasiswa }\end{array}$ & Kalimat yang seharusnya & Jenis \\
\hline 1 & $\begin{array}{l}\text { He is a journalist of } \\
\text { Indonesian }\end{array}$ & He is an Indonesian journalist & $\begin{array}{l}\text { Misordering: noun } \\
\text { functions as an } \\
\text { adjective }\end{array}$ \\
\hline
\end{tabular}

Berikut ini rekapitulasi hasil kesalahan gramatika pada esai mahasiswa Prodi Bahasa Inggris.

Tabel 5. Rekapitulasi Bentuk Kesalahan Esai Bahasa Inggris Mahasiswa

\begin{tabular}{|l|l|c|c|c|}
\hline No & \multirow{2}{*}{ Bentuk Kesalahan } & \multicolumn{3}{|c|}{ Jumlah } \\
\cline { 3 - 5 } & & Kesalahan & Responden & $\begin{array}{c}\text { Persentase } \\
(\%)\end{array}$ \\
\hline 1 & Omission & 35 & 7 & 29,17 \\
\hline 2 & Addition & 14 & 4 & 11,7 \\
\hline 3 & Misformation & 69 & 10 & 57,5 \\
\hline 4 & Misordering & 2 & 2 & 1,7 \\
\hline
\end{tabular}


Tabel 6. Rekapitulasi Jenis Kesalaham Esai Bahasa Inggris Mahasiswa

\begin{tabular}{|c|c|c|c|c|}
\hline \multirow[t]{2}{*}{ No } & \multirow[t]{2}{*}{ Jenis Kesalahan } & \multicolumn{3}{|c|}{ Jumlah } \\
\hline & & Kesalahan & Responden & $\begin{array}{c}\text { Persentase } \\
(\%)\end{array}$ \\
\hline $\mathbf{A}$ & \multicolumn{4}{|l|}{ Omission } \\
\hline a. 1 & Articles & 10 & 6 & 8,33 \\
\hline a. 2 & Noun/Pronoun & 12 & 7 & 10 \\
\hline a.3 & Preposition & 3 & 3 & 2,5 \\
\hline a. 4 & To be & 6 & 6 & 5 \\
\hline a.5 & To infinitive & 4 & 3 & 3,33 \\
\hline $\mathbf{B}$ & \multicolumn{4}{|l|}{ Addition } \\
\hline b.1 & To be & 4 & 4 & 3,33 \\
\hline b. 2 & Preposition & 5 & 2 & 4,17 \\
\hline b. 3 & Noun/Pronoun & 1 & 1 & 0,83 \\
\hline b.4 & Article & 3 & 1 & 2,5 \\
\hline b.5 & To infinitive & 1 & 1 & 0,83 \\
\hline $\mathbf{C}$ & \multicolumn{4}{|l|}{ Misformation } \\
\hline c. 1 & Main Verb & 27 & 10 & 22,5 \\
\hline c. 2 & Auxiliary Verb & 5 & 4 & 4,17 \\
\hline c. 3 & Noun/Pronoun & 5 & 3 & 0,83 \\
\hline c. 4 & Adjective & 2 & 1 & 1,67 \\
\hline c. 5 & Parallel Structure & 7 & 5 & 5,83 \\
\hline c. 6 & Singular/Plural For, & 14 & 7 & 11,67 \\
\hline c. 8 & Preposition & 9 & 8 & 7,5 \\
\hline D & \multicolumn{4}{|l|}{ Misordering } \\
\hline d.1 & Adverb & 1 & 1 & 0,83 \\
\hline d. 2 & Adjective & 1 & 1 & 0,83 \\
\hline
\end{tabular}

\section{Simpulan}

Dari penjelasan di atas dapat disimpulkan bahwa esai karya mahasiswa Program Studi Bahasa Inggrismasih banyak ditemukan kesalahan gramatika khususnya pada kategori misformation yang merupakan kesalahan bentuk namun paling mendominasi, yaitu 57,5\% berupa 69 bentuk kesalahan seperti pemilihan unsur verba (tidak sesuai tenses),noun/pronoun, adjective, parallel structure, preposition dan singular-plural form. Sedangkan omission $29,17 \%$ berupa35bentuk kesalahan seperti omission pada articles, subject (noun/pronoun), preposition, to infinitivedan unsur tobe.Kesalahan additionsebanyak 11,7\% yang berjumlah 14kesalahan seperti addition unsur tobe, preposition, noun/pronouns, articles dan to infinitive.Adapun kesalahan yang memiliki prosentase terendah adalah misordering $1.7 \%$ berupa 2 bentuk kesalahan yaitu adjective dan adverb. Sehingga total kesalahan berjumlah 155 kesalahan. 


\section{Saran dan Solusi}

Karena pengaruh bahasa Indonesia menjadi penyebab paling besar terjadi kesalahan gramatika ini, mahasiswa perlu diberi waktu cukup untuk lebih banyak mempelajari tata bahasa Inggris, khususnya pada aturan tata bahasa yang memiliki pola yang sangat berbeda dengan pola bahasa Indonesia, seperti singular-plural yang tidak memiliki aturan yang sama antara Bahasa Indonesia dan Bahasa Inggris. Kata sandang (articles) dalam Bahasa Indonesia bukan merupakan penentu dalam kalimat sedangkan sebaliknya, articles dalam Bahasa Inggris sangatlah menjadi penentu. Kesalahan penggunaan preposition dan pronouns perlu diajarkan lebih intensif. Unsur $S_{-} V$ Agreement yang juga muncul dalam kesalahan mahasiswa perlu diajarkan secara intensif sehingga mahasiswa dapat menerapkan aturannya secara benar. Pemberian materi ini akan lebih baik dilakukan dengan memberikan banyak latihan sehingga pola kalimat yang sering mereka buat secara salah dapat diingat lebih mudah dan dapat dipahami dan digunakan secara bawah sadar.

Dosen perlu melakukan metode peer correction antar mahasiswa satu dengan yang lainnya sehingga mahasiswa mengetahui bentuk kesalahan sekaligus memperbaiki kesalahan yang dilakukan sehingga tidak terulang kembali pada penulisan esai berikutnya.

Penanganan kesalahan gramatika harus dilakukan secara hati-hati dan diupayakan agar mahasiswa tidak merasa 'salah' yang akhirnya dapat menurunkan motivasi mereka untuk menggunakan Bahasa Inggris. Perbaikan kesalahan gramatikal sebaiknya dilakukan dengan yang tepat.

\section{Daftar Pustaka}

- Dulay, H.C., Burt, M., Krashen, S. (1981). Language Two. Newbury House: Rowley Mass

- Delahunty, Gerald P. and James Garvey. (2010). The English Language: from Sound to Sense. Indiana. Parlor Press

- Downing, Angela dan Philip Locke. (2006). English Grammar. A University Course. Second Edition. New York: Routledge

- Ellis, Rod and Gary Barkhuizen. (2005). Analyzing Learner Language. New York. Oxford University Press

- Gebhardt \& Dawn Rodrigues. (1989). TheCambridge Encyclopedia of Language. Cambridge: Cambridge University Press

- James. (1998). Errors in Language Learning and Use: Exploring Error Analysis.

- Lewis, Michael. (1993). The Lexical Approach. Howe: LTP Teacher Training

- Paulston, Cristina,B. dan Mary,Newton, Bruder. (1976). Teaching English as a Second Language. Techniques and Prosedures. Boston: Little, Brown and Company

- Sudaryanto.(1993). Metode dan Aneka Teknik Analisis Bahasa: Pengantar Penelitian Wahana Kebudayaan secara Linguistis. Yogyakarta: Duta Wacana University Press

- Thomson, A. J. dan A. V. Martinet. (1986). A Practical English Grammar. London. Oxford University Press 